\title{
Relationship between obstructive lung disease and non-small cell lung cancer
}

\author{
Takaki Akamine ${ }^{1}$, Tetsuzo Tagawa ${ }^{2}$, Masaki Mori ${ }^{2}$ \\ ${ }^{1}$ Department of Surgery, Saiseikai Fukuoka General Hospital, Fukuoka, Japan; ${ }^{2}$ Department of Surgery and Science, Graduate School of Medical \\ Sciences, Kyushu University, Fukuoka, Japan \\ Correspondence to: Tetsuzo Tagawa, PhD. Department of Surgery and Science, Graduate School of Medical Sciences, Kyushu University, 3-1-1 \\ Maidashi, Higashi-ku, Fukuoka 812-8582, Japan. Email: t_tagawa@surg2.med.kyushu-u.ac.jp. \\ Provenance and Peer Review: This is an invited article commissioned and reviewed by the Section Editor Dr. Shuangiiang Li (Department of Thoracic \\ Surgery and West China Medical Center, West China Hospital, Sichuan University, Chengdu, China). \\ Response to: Alifano M. Obstructive lung disease in smokers and never smokers: further insights in patient-related approach in lung cancer \\ understanding. J Thorac Dis 2019;11:S1310-2.
}

Submitted Nov 09, 2019. Accepted for publication Nov 29, 2019.

doi: $10.21037 /$ jtd.2019.12.09

View this article at: http://dx.doi.org/10.21037/jtd.2019.12.09

We would like to thank Dr. Alifano for his valuable comments on our study about the prognostic impact of obstructive lung disease on the survival of never smokers with resected non-small cell lung cancer (NSCLC) $(1,2)$.

Several studies have investigated the impact of chronic obstructive pulmonary disease (COPD) on the prognosis of patients with NSCLC. We can expect that patients with COPD have worse prognosis than those who do not. This may be due to the high risk of death from diseases other than lung cancer, such as chronic respiratory disease and cardiovascular disease. Therefore, we investigated the effect of obstructive lung disease on cancer-specific survival of lung cancer in our study (2).

Recently, a meta-analysis ( $\mathrm{n}=10$ studies) demonstrated that there was no significant difference in post-operative survival in early-stage lung cancer between patients with and without mild-to-moderate COPD (3). In this review, there was also a subset analysis of the National Lung Screening Trial. This subset was composed of high-risk smokers who were screened and followed up after detection or treatment of lung cancer. The analysis revealed that the overall 5-year survival after surgery of early-stage NSCLC in smokers with and without COPD was not significantly different ( 84 and $81 \%$ respectively, $\mathrm{P}=0.65$ ) (3). These data were consistent with our data showing that airflow limitation or obstructive lung disease did not affect cancer- specific survival in smokers with NSCLC (2).

As Dr. Afiliano mentions, consideration of epidemiological differences is important in understanding the analysis of patients' prognosis with COPD or NSCLC. As smoking prevalence varies in different nations (4), we fully agree with this opinion. Thus, epidemiological differences may influence the results of the systematic review described above.

We demonstrated that obstructive lung disease was an independent prognostic factor in never smokers with NSCLC (2). As Dr. Alifano states, our data may indicate that host status influences the tumor's immune microenvironment, which leads to a more aggressive biological phenotype. Recently, alterations in the tumor immune microenvironment in NSCLC caused by COPD, especially regarding immune cell composition, have been reported. Alifano and coworkers showed that exhausted CD8 tumor-inflating T lymphocytes, which lead to cancer immune escape, were exacerbated in COPD patients with NSCLC (5). Furthermore, Mark et al. observed increased Th1 lymphocytes in both the lung and tumor immune microenvironment in COPD patients with NSCLC (6). Interestingly, they also demonstrated that the presence of COPD is associated with an improved response to immune checkpoint inhibitors (6). Therefore, we can expect that the tumor immune microenvironment may have important 
therapeutic implications.

As Dr. Afiliano highlighted, these studies are mostly focused on COPD patients who smoke. The epidemiology of smoking has changed and the proportion of never smokers with NSCLC has been increasing (7). Based on the comments of Dr. Afiliano, we would like to perform a molecular analysis of the tumor immune environment of never smokers with NSCLC for further insights into tumor-host immune interactions.

\section{Acknowledgments}

We thank H. Nikki March, PhD, from Edanz Group (www.edanzediting.com/ac) for editing a draft of this manuscript.

Funding: None.

\section{Footnote}

Conflicts of Interest: The authors have no conflicts of interest to declare.

Ethical Statement: The authors are accountable for all aspects of the work in ensuring that questions related to the accuracy or integrity of any part of the work are appropriately investigated and resolved.

Open Access Statement: This is an Open Access article distributed in accordance with the Creative Commons Attribution-NonCommercial-NoDerivs 4.0 International License (CC BY-NC-ND 4.0), which permits the noncommercial replication and distribution of the article with the strict proviso that no changes or edits are made and the original work is properly cited (including links to both the formal publication through the relevant DOI and the license).
See: https://creativecommons.org/licenses/by-nc-nd/4.0/.

\section{References}

1. Alifano M. Obstructive lung disease in smokers and never smokers: further insights in patient-related approach in lung cancer understanding. J Thorac Dis 2019;11:S1310-2.

2. Akamine T, Tagawa T, Shimokawa M, et al. The prognostic impact of obstructive lung disease on survival of never smokers with resected non-small-cell lung cancer: a comparison with smokers. Interact Cardiovasc Thorac Surg 2019;28:735-43.

3. Hopkins RJ, Ko J, Gamble GD, et al. Airflow limitation and survival after surgery for non-small cell lung cancer: Results from a systematic review and lung cancer screening trial (NLST-ACRIN sub-study). Lung Cancer 2019;135:80-7.

4. GBD 2015 Tobacco Collaborators. Smoking prevalence and attributable disease burden in 195 countries and territories, 1990-2015: a systematic analysis from the Global Burden of Disease Study 2015. Lancet 2017;389:1885-906.

5. Biton J, Ouakrim H, Dechartres A, et al. Impaired Tumor-Infiltrating T Cells in Patients with Chronic Obstructive Pulmonary Disease Impact Lung Cancer Response to PD-1 Blockade. Am J Respir Crit Care Med 2018;198:928-40.

6. Mark NM, Kargl J, Busch SE, et al. Chronic Obstructive Pulmonary Disease Alters Immune Cell Composition and Immune Checkpoint Inhibitor Efficacy in NonSmall Cell Lung Cancer. Am J Respir Crit Care Med 2018;197:325-36.

7. Pelosof L, Ahn C, Gao A, et al. Proportion of NeverSmoker Non-Small Cell Lung Cancer Patients at Three Diverse Institutions. J Natl Cancer Inst doi: 10.1093/jnci/ djw295.
Cite this article as: Akamine T, Tagawa T, Mori M. Relationship between obstructive lung disease and non-small cell lung cancer. J Thorac Dis 2020;12(3):1145-1146. doi: 10.21037/ jtd.2019.12.09 